\title{
Status Analysis of Kasturba Gandhi Balika Vidayala (KGBV) in Ganjam District
}

\author{
Madhuchhanda Samantaroy ${ }^{1}$, Dr Arundhati Rath² \\ ${ }^{1} \mathrm{PhD}$ Research scholar, ${ }^{2}$ Professor \\ 1,2Department of Home Science, Berhampur University, Ganjam, Odisha
}

\begin{abstract}
How to cite this paper: Madhuchhanda Samantaroy | Dr Arundhati Rath "Status Analysis of Kasturba Gandhi Balika Vidayala (KGBV) in Ganjam District" Published in International Journal of Trend in Scientific Research and Development (ijtsrd), ISSN: 24566470, Volume-3 | Issue-3, April 2019, pp.1357-1362, URL: https://www.ijtsrd.c om/papers/ijtsrd23 358.pdf

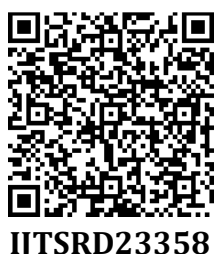

Copyright (C) 2019 by author(s) and International Journal of Trend in Scientific Research and Development Journal. This is an Open Access article distributed under the terms of the Creative Commons

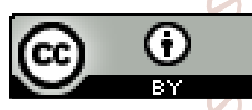
Attribution License (CC BY 4.0) (http://creativecommons.org/licenses/ by/4.0)

India is one of the largest democratic country in the world. It has a systematic education system which has a huge demand. But after 67 years of independence of India we are away from the goal of universal literacy. Till now, SC/ST/Woman rural people etc. are considered as deprived social group of our society in every side. They are suffering from a lot of problems and cannot go ahead of course. Government of India be either announces many welfare schemes for weaker section of our society time to time. These schemes could be either central, state specific or a joint collaboration between centre and state.

Looking at the enrolment level in elementary as well as appear primary classes and the retentionin. Significant gaps at the elementaramon still persist in rural as well as level as well as among disadvantages communities in upper primary level.However,the Government of India has introduced a Kasturba Gandhi Balika Vidayalaya (KGBV) scheme for setting up residential schools with all facilities at elementary level for girls belonging predominantly to Scheduled Caste, Scheduled Tribe, Other Backward Class and Minority Community with the objectivies to ensure equal opportunity and to improve berrier free environment to girls. The Kasturba Gandhi Balika Vidyalaya (KGBV) scheme was launched by the Government of India in August 2004 for setting up residential schools at upper primary level for girls belonging predominantly to the SC, ST, OBC and Minorities in the difficult areas. KGBV scheme provides for a minimum reservation of $75 \%$ of the seats for girls belong to SC, ST, $\mathrm{OBC}$ or Minority Communities and priority for the remaining $25 \%$ is accorded to girls from families Below Poverty Line(BPL).KGBV run as a separate scheme but in harmony with the Sarva Shiksha Abhiyan (SSA). SSA is Government of India's flagship programme for achievement of Universalization of Elementary Education (UEE) in a time bound manner making free and compulsory education to the children of 6 - 14 years age group. Sarva Shiksha Abhiyan (SSA) has a special focus on girl's education and children with special needs. Sarva Shiksha Abhiyan (SSA) also seeks to provide computer education to bridge the digital divide.

Since its Educationally Backward Blocks (EBBs), where the rural female literacy is below national average (46.13\% Census 2001) and gender in liiteracy is more than the national average (21.59\% Census 2001) among blocks.

In the context of above scenario this paper is an attempt to analiyse the status of KGBV in different blocks of Orissa state. Thus the objective of the study are fofmulated as :

1. To study the enrolment status of the KGBV in selected blocks of Ganjam district.

2. To know the infrastructure and facilities of KGBV.

3. To understand the life style of hostel dwellers of (KGBV) students in Ganjam district. 
4. To study food consumption pattern of students of Kasturba Gandhi Balik Vidayala(KGBV) .

5. To assess various facilities provided to the students of KGBV in the hostel.

6. To study about vocational training provided to the students of KGBV.

7. To know the views of students of KGBV regarding their problems and their suggestion for betterment of KGBV.

Need of the study:

Directive principle of state policy through Article 45 states that the state should provide free and compulsory education to all children of age of 14 . Article 46 of our constitution states to promote the educational need of weaker sections of the society( SC, ST, OBC). As per this constitutional obligations through national policy of education various steps are taken for the girls education in our state. A number of centrally sponsored scheme are being continued, Kasturba Gandhi Balika Vidyalaya (KGBV) is one of them for improve girl child education of SC, ST, OBC, BPL and educationally backward classes. The main aim of study is to know about educational facilities and problems of Kasturba Gandhi Balika Vidyalaya (KGBV) hostel students in Ganjam district.

\section{SCOPE OF THE STUDY:}

There are 17 KGBV in Ganjam district of Odisha state out of which the researcher has selected five number of blocks. Thus the scope of this study has been confined to Kukudakhandi block, Hinjilicut block of Gopinathpur, Chhatrapur block of Rickapalli, Chikiti block of Ramachandrapur, Digapahandi block of Padmanavpur of Ganjam district. 100 number of samples selected from each Kasturba Gandhi Vidyalaka (KGBV) randomly for the purpose of the study.

\section{METHODOLOGY:}

Tools and Tenchiques used:

In the present study primary data have been used. The researcher had prepared a set of questionnaire and open interview schedule to collect data further students of KGBV.The interviewing had later gone through a piolet study and the modification were being done looking in view the objects of the study.

The researcher had picked up 500 number of samples randomnly for the present study. The samples were choosen from all the categories of SC,ST,OBC and BPL students of five blocks ofKasturba Gandhi Balika Vidyalaya (KGBV) of
Ganjam district. From each school 100 number of samples were picked up randomly for be purpose.

\section{PROCEDURE OF DATA COLLECTION: -}

Researcher had selected five Kasturba Gandhi Balika Vidyalaya (KGBV) randomly from selected five blocks of Ganjam district. The researcher went for collection of data after obtaining formal permission from the Block Education Officer (BEO)/ Headmaster / Headmistress of different KGBV of Ganjam district and visited selected KGBV of Ganjam district during August and September,2014 for collection of data. The researcher personally met the students of KGBVs five blocks. Researcher also met Headmaster/Headmistress and teachers for collection of information through questionnaire. Researcher prepared questionnaire for the sample groups. The researcher conducted a pilot study and modified the questionare as required.

The researcher fastor interested with the Headmaster/Headmistress and collected infofmation by using questionare. The questionare comprises two parts,first part is connected with school profile and the second set of schedule is with regard to various facilities,services and problems of KGBVs.Researcher talked with the samples and interacted with them about by using questionnaire method and personal interview method regarding various facilities provided by Central Government and different problems faced by them in the hostel.After collection of data the researcher compiled the data and analysed the information by using numerical and percentage statistical method.

\section{Result Analysis:}

The data collected by the researcher has been analyzed under the following sub headings:

\section{Enrolment status:}

Table No. 1 shows student strength of different classes of KGBV of all five blocks. The data in the table reflects that in class $6^{\text {th }}$ there were 8 number of students, in 7 th class 39 number of students and in 8th class 53 number of students were enrolled in the year 2014 in Kukudakhandi block. In Hinjili block of Gopinathpur KGBV 30 number of students in 6th class, in 7th class 34 number of students and in 8th class 36 number of students were studying. In Chhatrapur block of Rickapalli. in $6^{\text {th }}$ class 31 number of students, in $7^{\text {th }}$ class 29 number of students and in $8^{\text {th }}$ class 40 number of students were enrolled.

Table No. 1

\begin{tabular}{|} 
Enrolment Status in KGBV (Block wise) \\
\begin{tabular}{|c|c|c|c|c|c|}
\hline S.. & $\begin{array}{c}\text { Name of Kasturba Gandhi Balika } \\
\text { Vidyalaya (KGBV)(Block wise) }\end{array}$ & VI & VII & VIII & Total \\
\hline 1 & Kukudakhandi & 8 & 39 & 53 & 100 \\
\hline 2 & Hinjili & 30 & 34 & 36 & 100 \\
\hline 3 & Chhatrapur & 31 & 29 & 40 & 100 \\
\hline 4 & Digapahandi & 4 & 44 & 52 & 100 \\
\hline 5 & Chikiti & 29 & 46 & 25 & 100 \\
\hline \multicolumn{2}{|c|}{ Total } & $\mathbf{1 0 2}(\mathbf{2 0 . 4 \% )}$ & $\mathbf{1 9 2}(\mathbf{3 8 . 4 \% )}$ & $\mathbf{2 0 6 ( 4 1 . 2 \% )}$ & $\mathbf{5 0 0 ( 1 0 0 \% )}$ \\
\hline
\end{tabular}
\end{tabular}

(Figures in parenthesis indicate percentage)

In Digapahandi block of Padmanavpur Kasturba Gandhi Balika Vidyalaya (KGBV) 100 number of students were enrolled. In 6th class 4 number of students, in 7 th class 46 number of students and in $8^{\text {th }}$ class 52 number of students were enrolled. In Chikiti block of Ramachandrapur Kasturba Gandhi Balika Vidyalaya (KGBV) 100 number of students were enrolled where in 6th class 29 number of students, in 7th class 46 number of students and in 8th class 25 number of students were studying. In all the KGBV of five blocks of total number of students were 500 where in 6th class $102(20.4 \%)$ number of students, in 7 th class 192 (38.4\%) number of students and in 8th class 206(41.2\%) number of students were enrolled. 
Table No. 2 shows in Kukudakhandi KGBV there were $22(22 \%)$ number of dropout students enrolled in $6^{\text {th }}$ class and $2(2 \%)$ number of dropout students enrolled in Ramachadrapur KGBV in class $6^{\text {th }}$, thus 24 (4.8\%) number of dropout students were enrolled

Table No. 2 Enrolment Status of Dropout Students in KGBV(Block wise)

\begin{tabular}{|c|c|c|}
\hline SI. No. & Name of the Kasturba Gandhi Balika Vidyalaya (KGBV) (Block wise) & No. of Students (\%) \\
\hline 1 & Kukudakhandi & $22(22 \%)$ \\
\hline 2 & Hinjili & - \\
\hline 3 & Chhatrapur & - \\
\hline 4 & Digapahandi & $2(2 \%)$ \\
\hline 5 & Chikiti & $24(4.8 \%)$ \\
\hline
\end{tabular}

(Figures in parenthesis indicates percentage)

\section{FOOD PATTERN IN THE HOSTEL:}

Table No. 3 shows that their early morning breakfast used to be 6 pieces of biscuits from Sunday to Saturday, all holidays, festivals between 6.30 AM to 7AM. The students used to take school mid-day meal as their lunch from Monday to Saturday between $1 \mathrm{PM}$ to $1.30 \mathrm{PM}$. A little variation was found on holidays and festivals for breakfast, lunch, evening tiffin and dinner. On Sunday breakfast they took suji halwa and banana between 9AM to 9.30AM.

\begin{tabular}{|c|c|c|c|c|c|}
\hline Day & $\begin{array}{c}\text { Early morning } \\
\text { breakfast } 6.30 \text { to } \\
7 \mathrm{AM}\end{array}$ & $\begin{array}{l}\text { Breakfast 9AM } \\
\text { to } 9.30 \mathrm{AM}\end{array}$ & $\begin{array}{l}\text { Lunch } \\
\text { 1PM to } 1.30 \mathrm{PM}\end{array}$ & $\begin{array}{l}\text { Evening Tiffin } \\
\text { 5.30PM to 6PM }\end{array}$ & $\begin{array}{c}\text { Dinner } \\
\text { 9PM to 9.30PM }\end{array}$ \\
\hline Sunday & Biscuit 6 Piece & $\begin{array}{l}\text { Suji Halwa, } \\
\text { Banana }\end{array}$ & $\begin{array}{l}\text { Rice, dal, chicken } \\
\text { curry for vegetarian } \\
\text { paneer, salad }\end{array}$ & $\begin{array}{l}\text { Puffed rice } \\
\text { mixture }\end{array}$ & $\begin{array}{l}\text { Rice/roti, dalma, } \\
\text { potherb bhaja (sago) }\end{array}$ \\
\hline Monday & Biscuit 6 Piece & $\begin{array}{l}\text { Suji Upama, } \\
\text { Dalma }\end{array}$ & $\begin{array}{l}\text { School mid-day } \\
\text { meal }\end{array}$ & $\begin{array}{l}\text { Sprouted } \\
\text { moong, sugar, } \\
\text { zaggry }\end{array}$ & $\begin{array}{l}\text { Rice/roti, soyabin } \\
\text { curry, bhaja, pickle }\end{array}$ \\
\hline Tuesday & Biscuit 6 Piece & Sattu, Ragi, Milk & $\begin{array}{l}\text { School mid- day } \\
\text { meal I J ournal }\end{array}$ & Semiya kheer & $\begin{array}{l}\text { Rice/roti, rajama } \\
\text { curry/todaka, bhaja, } \\
\text { pickle }\end{array}$ \\
\hline Wednesday & Biscuit 6 Piece & $\begin{array}{l}\text { Chuda upama, } \\
\text { Dalma }\end{array}$ & $\begin{array}{l}\text { School mid-day } \\
\text { meal } h \text { and }\end{array}$ & $\begin{array}{l}\text { Chick-boiled } \\
\text { (buto) }\end{array}$ & $\begin{array}{l}\text { Rice/roti, egg curry, } \\
\text { veg pamapada, } \\
\text { pickle }\end{array}$ \\
\hline Thursday & Biscuit 6 Piece & $\begin{array}{l}\text { Hotch potch of } \\
\text { rice and spices ISS } \\
\text { (Khichidi) Curry, } \\
\text { pickle }\end{array}$ & $\begin{array}{l}\text { School mid-day } \\
\text { meal }\end{array}$ & Pea-boil & $\begin{array}{l}\text { Rice, drumstick } \\
\text { curry, patato, brinjle, } \\
\text { cakes of pasted } \\
\text { pluse, (bodi) pickle, } \\
\text { pampada }\end{array}$ \\
\hline Friday & Biscuit 6 Piece & Idle, Pea Curry & $\begin{array}{l}\text { School mid-day } \\
\text { meal }\end{array}$ & Pokoda & $\begin{array}{l}\text { Rice/roti, chlick } \\
\text { (Buto) curry, pickle }\end{array}$ \\
\hline Saturday & Biscuit 6 Piece & Puri, Patato curry & $\begin{array}{l}\text { School mid- day } \\
\text { meal }\end{array}$ & $\begin{array}{l}\text { Chat, Pea-curry } \\
\text { Onion, pampada }\end{array}$ & $\begin{array}{l}\text { Rice, fish curry, } \\
\text { basan curry, chips, } \\
\text { salad }\end{array}$ \\
\hline $\begin{array}{l}\text { Holidays \& } \\
\text { Festivals }\end{array}$ & Biscuit 6 Piece & $\begin{array}{l}\text { Puri, Patato curry, } \\
\text { sweets }\end{array}$ & $\begin{array}{l}\text { Rice, dal, chicken } \\
\text { curry for vegetarian } \\
\text { paneer, salad }\end{array}$ & $\begin{array}{l}\text { Chick-boiled } \\
\text { (Buto) }\end{array}$ & Parata, Dalma, Milk \\
\hline
\end{tabular}

They took their lunch between 1PM to 1.30PM. Sunday lunch included rice, dal, chicken curry, for vegetarian they were given paneer curry and salad. They took puffed rice mixture as evening tiffin between 5.30PM to 6PM on Sunday. Sunday dinner included rice, dal/roti, dalma, potherb (sago) bhaja between 9PM to 9.30PM.The students of Kasturba Gandhi Balika Vidyalaya (KGBV) used to take mid-day meal as their lunch from Monday to Saturday between 1 PM to 1.30PM. Monday's breakfast was suji upama and dalma. They were taking sprouted moong dal with sugar/jaggry as Monday evening tiffin between 5.30 PM to 6 PM. They were taking rice/roti, soyabin curry, bhaja, pickle as dinner between 9PM to 9.30PM on Monday. On Tuesday they had sattu, ragi and milk as their breakfast between 9AM to $9.30 \mathrm{AM}$. They had semiya kheer as evening tiffin between $5.30 \mathrm{PM}$ to 6PM. Tuesday dinner included rice, roti, rajama curry, tadoka and pickle between 9PM to 9.30 PM. On Wednesday they were taking chuda upama and dalma between 9AM to 9.30AM as their breakfast. They ate boiled pea (buto) as evening tiffin between $5.30 \mathrm{PM}$ to 6PM. In dinner they were taking rice/roti, egg curry for vegetarian pickle and pampada between 9PM to 9.30PM on Wednesday. On Thursday they had hotch potch of rice and spieces (Khichidi) patato curry and pickle as their breakfast between 9AM to 9.30 AM. They were taking peas (boiled) as evening tiffin between 5.30 PM to 6Pm. In dinner rice, drumstick curry, patato, brinjle, cakes of pasted rice (bodi) pickle and pampada were served between 9PM to 9.30PM on Thursday. On Friday they were taking Idli, Pea curry as their breakfast between 9AM to 9.30AM, they took pokoda as their evening tiffin between 5.30PM to 6PM, and in dinner rice/roti, chick (buto) curry, pickle were served between 9PM to 9.30PM on Friday. On Saturday they ate puri, patato curry as their breakfast. They ate chat-pea curry, onion, pampada as their evening tiffin. They in dinner rice, fish curry, basan curry, chips and salad were served between 9PM to 9.30PM on Saturday. On holidays and festivals 
days puri, potato and sweets as were served their breakfast. They were taking rice, dal, paneer curry, salad, pampada, and khata as lunch between $1 \mathrm{Pm}$ to 1.30 PM, on holidays and festivals. They were eating chick (buto) boiled as their evening tiffin. In dinner dinner paratha, dalma and milk were served between 9PM to 9.30PM on holidays and festivals.

\section{PATTERN OF LIVING:}

Table No.4 shows the pattern of living style from Monday to Friday in a week. The students used to get up from bed around 5 $\mathrm{AM}$ in the morning and they finished their daily routine between 6AM. Thereafter they used to attend prayer, drill and yoga till 6.30 AM. After 6.30AM they were attending gardening and school cleaning work (up to 7AM). Thereafter they had remedial teaching classes taken by part time teachers from 7AM to 9AM and they take their breakfast from 9AM to 9.30AM. During 9.30 $\mathrm{AM}$ to $10 \mathrm{AM}$ they used to get ready to go to school. They used to remain in the school from 10AM to 1PM and were attending their classes as per time table. They used to take their lunch between $1 \mathrm{PM}$ to $1.30 \mathrm{PM}$. After lunch again they were attending classes up to 4 PM. They took rest from 4 PM to 4.30 PM in the hostel. From 4.30 PM to 5.30 PM they used to pray. Again they had their prayer and then they read newspaper till 6.30 PM. Again they used to attend

Table no-4 (KGBV) (Monday to Friday)

\begin{tabular}{|c|c|c|c|c|c|}
\hline \multicolumn{2}{|r|}{ Morning } & \multicolumn{2}{|c|}{ Afternoon } & \multicolumn{2}{|c|}{ Evening } \\
\hline $\begin{array}{l}5 \mathrm{AM} \\
\text { to } 6 \mathrm{AM}\end{array}$ & Daily work & $\begin{array}{l}\text { 10AM to } \\
1 \mathrm{PM}\end{array}$ & $\begin{array}{c}\text { school } \\
\text { hours study }\end{array}$ & $4.30 \mathrm{PM}$ to $5.30 \mathrm{PM}$ & Playing \\
\hline $\begin{array}{l}6 \mathrm{AM} \text { to } \\
6.30 \mathrm{AM}\end{array}$ & Prayer, Drill, Yoga & $\begin{array}{l}\text { 1PM to } \\
1.30 \mathrm{PM}\end{array}$ & $\begin{array}{l}\text { Lunch } \\
\text { Break }\end{array}$ & $5.30 \mathrm{PM}$ to $6.30 \mathrm{PM}$ & $\begin{array}{c}\text { Prayer, reading } \\
\text { newspaper }\end{array}$ \\
\hline $\begin{array}{l}6.30 \mathrm{AM} \\
\text { to } 7 \mathrm{AM}\end{array}$ & $\begin{array}{l}\text { Gardening, School } \\
\text { clean }\end{array}$ & $\begin{array}{l}1.30 \mathrm{PM} \\
\text { to } 4 \mathrm{PM}\end{array}$ & $\begin{array}{c}\text { school } \\
\text { hours study }\end{array}$ & $6.30 \mathrm{PM}$ to $7.30 \mathrm{PM}$ & Life skill training \\
\hline $\begin{array}{l}7 \mathrm{AM} \\
\text { to } 9 \mathrm{AM}\end{array}$ & $\begin{array}{l}\text { Remedial teaching } \\
\text { by part time teacher }\end{array}$ & $\begin{array}{l}\text { 4PM to } \\
4.30 \mathrm{PM}\end{array}$ & Rest & $7.30 \mathrm{PM}$ to $8.30 \mathrm{PM}$ & $\begin{array}{l}\text { Remedial teaching } \\
\text { by part time teacher }\end{array}$ \\
\hline $\begin{array}{l}\text { 9AM to } \\
9.30 \mathrm{AM}\end{array}$ & Breakfast & & & $8.30 \mathrm{PM}$ to $9.30 \mathrm{PM}$ & Watching T.V. \\
\hline $\begin{array}{l}9.30 \mathrm{AM} \\
\text { to } 10 \mathrm{AM}\end{array}$ & Ready for school & & & $9.30 \mathrm{PM}$ to $10 \mathrm{PM}$ & Dinner \\
\hline & & 8 & & $10 \mathrm{PM}$ & Go to bed \\
\hline
\end{tabular}

life skill training class from 6.30PM to 7.30PM. From 7.30 PM to 8.30 PM they used to attend remedial teaching classes taken by part time teachers. After classes were over they used to watch television programmes from 8.30 PM to 9.30 PM. They finished their dinner between 10PM and thereafter they had their rest and sleep.

Table No.5 shows the pattern of living of Saturday. There was a little bit difference in programme of Saturday. On Saturday as usual they used to get up and finished their daily work between 5AM to 6AM. They attend prayer, yoga and drill between 6AM to $6.30 \mathrm{AM}$.

Table no- 5 Pattern of Living of Saturday of KGBV

\begin{tabular}{|c|c|c|c|c|c|}
\hline \multicolumn{2}{|c|}{ Morning } & \multicolumn{2}{c|}{ Afternoon } & \multicolumn{2}{c|}{ Evening } \\
\hline $\begin{array}{c}\text { 5AM to } \\
6 \mathrm{AM}\end{array}$ & Daily work & 10AM to 1PM & $\begin{array}{c}\text { school hours } \\
\text { study }\end{array}$ & 5.30PM to 6.30PM & $\begin{array}{c}\text { Prayer, reading } \\
\text { newspaper }\end{array}$ \\
\hline $\begin{array}{c}\text { 6AM to } \\
6.30 \mathrm{AM}\end{array}$ & $\begin{array}{c}\text { Prayer, Drill, } \\
\text { Yoga }\end{array}$ & 1PM to 1.30PM & Rest & 6.30PM to 8PM & $\begin{array}{c}\text { Learning different } \\
\text { song, dance, drawing }\end{array}$ \\
\hline $\begin{array}{c}\text { 6.30AM } \\
\text { to 7AM }\end{array}$ & $\begin{array}{c}\text { Ready for } \\
\text { school, } \\
\text { breakfast }\end{array}$ & $\begin{array}{c}1.30 \mathrm{PM} \text { to } 4 \\
\mathrm{PM}\end{array}$ & Gardening & 8PM to 9PM & $\begin{array}{c}\text { Remedial teaching } \\
\text { by part time teacher }\end{array}$ \\
\hline $\begin{array}{c}7 \mathrm{AM} \text { to } \\
11 \mathrm{AM}\end{array}$ & $\begin{array}{c}\text { school hours } \\
\text { study }\end{array}$ & $\begin{array}{c}4 \mathrm{PM} \text { to } 4.30 \\
\mathrm{PM}\end{array}$ & $\begin{array}{c}\text { Vocational } \\
\text { training }\end{array}$ & 9PM to 9.30PM & Watching T.V. \\
\hline & & & & $9.30 \mathrm{PM}$ to 10PM & Dinner \\
\hline
\end{tabular}

As on Saturday there was morning classes, they used to get themselves ready for school and had breakfast between $6.30 \mathrm{AM}$ to 7AM. From 7AM to till $11 \mathrm{AM}$ they were in the school, they took rest from 11AM to 3PM. They were doing gardening work from 3PM to 4PM. Thereafter had their prayer, read newspaper during 5.30PM to 6.30PM, from 6.30PM to 8PM they were attending different extracurricular activities such as dance, song and drawing. They attend remedial teaching classes from 8PM to 9PM. They used to take dinner between 9.30PM to 10PM. After dinner they used to go to bed at 10PM. Table No.6 shows the pattern of living on Sunday in Kasturba Gandhi Balika Vidyalaya (KGBV).

Table-6 Pattern of Living of Sunday of KGBV

\begin{tabular}{|c|c|c|c|c|c|}
\hline \multicolumn{2}{|c|}{ Morning } & \multicolumn{2}{c|}{ Afternoon } & \multicolumn{2}{c|}{ Evening } \\
\hline $\begin{array}{c}\text { 5AM to } \\
\text { 9AM }\end{array}$ & $\begin{array}{c}\text { Daily work, school boundary } \\
\text { and clean room, breakfast }\end{array}$ & $\begin{array}{c}11 \mathrm{AM} \text { to } \\
1 \mathrm{PM}\end{array}$ & $\begin{array}{c}\text { Vocational } \\
\text { Training }\end{array}$ & 6PM to 6.30PM & $\begin{array}{c}\text { Prayer, reading } \\
\text { newspaper }\end{array}$ \\
\hline $\begin{array}{c}\text { 9AM to } \\
11 \mathrm{AM}\end{array}$ & Health Checkup & $\begin{array}{c}1 \mathrm{PM} \text { to } \\
1.30 \mathrm{PM}\end{array}$ & $\begin{array}{c}\text { Meeting with } \\
\text { parents }\end{array}$ & 6.30PM to 7PM & Student union \\
\hline & & $4 \mathrm{PM}$ & Rest & 7PM to 9PM & Film show \\
\hline & & $\begin{array}{c}4 \mathrm{PM} \text { to } \\
4.30 \mathrm{PM}\end{array}$ & $\begin{array}{c}\text { Life skill } \\
\text { training }\end{array}$ & 10PM & Dinner and Sleep \\
\hline
\end{tabular}


On Sunday students of Kasturba Gandhi Balika Vidyalaya (KGBV) had their daily morning work between 5AM to 9AM. Thereafter they used to clean school boundary and school class room, then they used to take their breakfast. After breakfast they went health-checkup programme up to 11AM. They had vocational training programme from 11AM to 1PM. From $1 \mathrm{PM}$ to 3PM they were meeting their parents who had come from their villages. The students used to take rest from 3PM to 4PM. They were attending life skill training in the hostel from 4PM to 5PM. They were attending prayer and read newspaper from 6PM to 6.30PM. They took part in discussion of student union between 6.30 PM to 7.30 PM. Thereafter they were watching film show from 7PM to 9PM. After film show they had their dinner and at 10.PM they had their night sleep.

\section{FACILITIES:}

Table No. 7 shows various facilities provided to Kasturba Gandhi Balika Vidyalaya (KGBV) students. All the Kasturba Gandhi Balika Vidyalaya (KGBV) are provided with facilities of water, electricity, toilet, television, newspaper, warden, peon, watchman, teaching aid, holidays and vacations, telephone, kitchen room, playground, observation festival, scholarship, savings bank account, picnic, examination, vocational training, library, health-check-up, extra-curricular activities, meeting with parents, study material, note book, computer laboratory, all necessary of adolescent girls, play

\section{Table no-7 Facilities Provided in Kasturba Gandhi Balika Vidyalaya (KGBV)}

\begin{tabular}{|c|c|c|c|c|c|c|c|c|c|c|}
\hline \multirow{3}{*}{ Facilities } & \multicolumn{10}{|c|}{ Name of the Block } \\
\hline & \multicolumn{2}{|l|}{ Kukudakhandi } & \multicolumn{2}{|c|}{ Hinjili } & \multicolumn{2}{|c|}{ Chhatrapur } & \multicolumn{2}{|c|}{ Digapahandi } & \multicolumn{2}{|c|}{ Chikiti } \\
\hline & Yes & No & Yes & No & $\overline{\text { Yes }}$ & No & Yes & No & Yes & No \\
\hline Water supply & Yes & & Yes & & Yes & & Yes & & Yes & \\
\hline Electricity & Yes & & Yes & & Yes & & Yes & & Yes & \\
\hline Toilet & Yes & & Yes & & Yes & & Yes & & Yes & \\
\hline Television & Yes & & Yes & & Yes & & Yes & & Yes & \\
\hline Newspaper & Yes & & Yes & & Yes & & Yes & & Yes & \\
\hline Warden & Yes & $\pi$ & Yes & & Yes & & Yes & & Yes & \\
\hline Peon & Yes & & Yes & 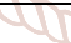 & Yes & & Yes & & Yes & \\
\hline Watchman & Yes & Sc & Yes & sers & Yes & & & No & Yes & \\
\hline Teaching aid & Yes no & 0 & Yes & -1 & Yes & & Yes & & Yes & \\
\hline Holiday and vacation & Yes & & Yes & $\theta_{0}$ & Yes & & Yes & & Yes & \\
\hline Uniform & Yes & $T C$ & Yes & & Yes & $\bar{\gamma}$ & Yes & & Yes & \\
\hline Telephone & Yes & & Yes & & 0 & No & Yes & & Yes & \\
\hline Kitchen room & Yes Intern & atio & Yes & urm & Yes & 0 & Yes & & Yes & \\
\hline Mid day meal & Yes & 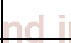 & Yes & sntif & Yes & $\gamma$ & Yes & & Yes & \\
\hline Proper food & Yes & & Yes & & Yes & 8 & Yes & & Yes & \\
\hline Observation festival & Yes & & Yes & 10 & Yes & 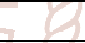 & Yes & & Yes & \\
\hline Scholarship & Yes & Eer & Yes & nt: & Yes & 8 & Yes & & Yes & \\
\hline Savings bank a/c & Yes & & Yes & & Yes & 8 & Yes & & Yes & \\
\hline Picnic & Yes & $1: 24$ & Yes & 10 & Yes & $E$ & Yes & & Yes & \\
\hline Examination & Yes & & Yes & $0^{\circ}$ & Yes & 8 & Yes & & Yes & \\
\hline Playground & Yes ? & 8 & Yes & & 6 & No & Yes & & Yes & \\
\hline Vocational training & Yes & - & Yes & है & Yes & & Yes & & Yes & \\
\hline Library & Yes & & Yes & 5 & Yes & & Yes & & Yes & \\
\hline Health Checkup & Yes & 0 & Yes & & Yes & & Yes & & Yes & \\
\hline Extracurricular activities & Yes & & Yes & & Yes & & Yes & & Yes & \\
\hline Meeting with parents & Yes & & Yes & & Yes & & Yes & & Yes & \\
\hline Study material & Name of the Block & & Yes & & Yes & & Yes & & Yes & \\
\hline
\end{tabular}

\begin{tabular}{|c|c|c|c|c|c|c|c|c|c|c|}
\hline \multirow{3}{*}{ Facilities } & \multicolumn{10}{|c|}{ Kukudakhandi } \\
\hline & \multicolumn{2}{|c|}{ Yes } & \multicolumn{2}{|c|}{ Hinjili } & \multicolumn{2}{|c|}{ Chhatrapur } & \multicolumn{2}{|c|}{ Digapahandi } & \multicolumn{2}{|c|}{ Chikiti } \\
\hline & Yes & No & Yes & No & Yes & No & Yes & No & Yes & No \\
\hline Note book & Yes & & Yes & & Yes & & Yes & & Yes & \\
\hline Computer Lab & Yes & & & No & Yes & & Yes & & Yes & \\
\hline $\begin{array}{l}\text { All necessities of } \\
\text { adolescent girl }\end{array}$ & Yes & & Yes & & Yes & & Yes & & Yes & \\
\hline Play equipments & Yes & & Yes & & Yes & & Yes & & Yes & \\
\hline School bag, pen, pencil & Yes & & Yes & & Yes & & Yes & & Yes & \\
\hline Umbrella & Yes & & Yes & & Yes & & Yes & & Yes & \\
\hline Shoes, Soap & Yes & & Yes & & Yes & & Yes & & Yes & \\
\hline Scale & Yes & & Yes & & Yes & & Yes & & Yes & \\
\hline Sampoo, Comb, hair oil & & & Yes & & Yes & & Yes & & Yes & \\
\hline Reading Room & & & & No & & No & & No & Yes & \\
\hline
\end{tabular}

equipments and personal articles like school bag, pen, pencils, umbrella, shoes, scale, comb, soap, hair oil and reading room. Gopinathpur KGBV of Hinjili block had no computer laboratory facilities for the students. Rickapalli KGBV of Chhatrapur block was no telephone, reading room, playground facilities to the students. Except in Ramchandrapur KGBV of Chikiti block all other four KGBV had no reading room facilities to the students. 
The most motivating facility provided in KGBV for the students was opening savings bank account for each students where Rs.50/- per month was deposited for them from class VI to VIII. Similar findings have been reported in the study of Baruah (2013) in Assam and Das (2013)

\section{VOCATIONAL TRANNING:}

Table No.8 shows in Kukudakhandi Kasturba Gandhi Balika Vidyalaya (KGBV) researcher had taken 100 number of students as sample group. Only 40 number of students were taking up dance training, 30 number of students were learning songs and 30 number of students were undergoing tailoring training. In Hinjili block of Gopinathpur Kasturba Gandhi Balika Vidyalaya (KGBV) researcher had taken 100 number of students as sample group. 50 number of students were taking up dance training, 30 number of students were learning songs, 10 number of students were undergoing tailoring training and 10 number of students were undergoing knitting training.

Table no-8 Samples Undergoing Vocational Training Programme in KGBV (Block wise)

\begin{tabular}{|c|c|c|c|c|c|c|c|}
\hline \multirow{2}{*}{$\begin{array}{l}\text { Sl. } \\
\text { No. }\end{array}$} & \multirow{2}{*}{$\begin{array}{c}\text { Name (of KGBV) } \\
\text { (Block wise) }\end{array}$} & Dance & Song & Tailor & Embroidery & Knitting & \multirow{2}{*}{$\begin{array}{c}\text { Students } \\
\text { Total Number of Samples }\end{array}$} \\
\hline & & \multicolumn{5}{|c|}{ Number of Samples } & \\
\hline 1 & Kukudakhandi & 40 & 30 & 30 & - & - & 100 \\
\hline 2 & Hinjili & 50 & 30 & 10 & - & 10 & 100 \\
\hline 3 & Chhatrapur & 40 & 20 & 30 & - & 10 & 100 \\
\hline 4 & Digapahandi & 50 & 30 & 20 & - & - & 100 \\
\hline 5 & Chikiti & 50 & 50 & - & - & - & 100 \\
\hline & Total & $230(46 \%)$ & $160(32 \%)$ & $90(18 \%)$ & - & $20(4 \%)$ & 500 \\
\hline
\end{tabular}

((Figures in parenthesis indicate percentage)

In Chhatrapur block of Rickapalli KGBV out of 100 students researcher had taken 100 number of students as sample group. 40 number of students were taking up dance training, 20 number of students were learning songs, 30 number of students were undergoing tailoring training and 10 number of students were undergoing knitting training. In Digapahandi block of Padmanavpur KGBV researcher had taken 100 number of students as sample group. 50 number of students were taking up dance traning, 30 number of students were learning songs and 20 number of students were undergoing tailoring training. In Chikiti block of Ramachadrapur(KGBV researcher had taken of 100 number of students as sample group where 50 number of students were taking up dance training, 50 number of students were learning songs. In all five blocks of Kasturba Gandhi Balika Vidyalaya (KGBV) in Ganjam district $46(46 \%)$ number of students were learning dance training, 32 (32\%) number of students were learning songs, $18(18 \%)$ number of samples were undergoing tailoring training and $4(4 \%)$ number of students were undergoing knitting training.

Participation of selected students in vocational training programmes of KGBV (Table no. 7) was satisfactory. The result shows that there were $46 \%$ of students taking up dance training, $32 \%$ of students were learning songs, $18 \%$ of students were undergoing tailoring training and $4 \%$ of students were undergoing knitting training. Similar findings were stated by Brhama (2012), Pradhan (2012) and Mishra (2012).

\section{MAJOR FINDINGS:}

1. Enrolment status of selected KGBV of five blocks were according to the guidelines but enrolment number of SC, ST, OBC, Minority Communities and BPL students were not according to guideline.

2. There were no dropout students in selected KGBV of five blocks during the year 2014. On the other hand dropout students other than the KGBV were enrolled in Ramachandrapur KGBV and Kukudakhandi KGBV.

3. The students of KGBV were attending various vocational training programmes.

4. The students of five KGBV were provided with food facilities as per menu.

5. The pattern of living facilities were as per chart provided by the Government.

\section{CONCULSION:}

The KGBV is meant for the improvement of education of SC, ST, OBC, BPL and Minority. It is the best facilities for the educationally backward students by the Government. KGBV residential school is to ensure access to quality education and to reduce the dropout and over aged girls of society. KGBV is a small school serving 100 girls but its reach however is far and wide. The vast majority of students at KGBV school are the first generation to be educated in their family.

In the present study the result and observation of the study show that the enrolment students of KGBV was more than satisfactory in case of SC,ST and OBC, but so far as BPL category was concerned the enrolment status was not up to the guideline. Various educational facilities like study material, class room teaching and toilet facilities where provided to all the KGBV. The students of KGBV were provided with different vocational training programmes like dance, song and tailoring. And residential facilities were also provided all the boarders of the hostel as per provision. But in few KGBV there were lack of separate classroom, library, playground, boundary wall, drinking water, watchmen and telephonic communication. It was also observed that all the KGBV students were found to be disciplined, cheerful, clean and well manner. To conclude it can be stated that even though all the KGBVs were functioning successfully, in some of the KGBVs problems were lying which should be properly monitored and taken care of for the better performance of KGBVs.

\section{RECOMMENDATIONS:}

[1] Provision should made by the Government for their higher education and better placement.

[2] The KGBVs should have only women staff in diffenent positions and responsibilities like head for the institution, teachers,office staff,warden and cooks.

\section{Reference:}

[1] Www.ganjam.nic.in

[2] Odisha HRD KGBv. Kasturba Gandhi. htm

[3] Barauah Rekhamoni IOsR journal of Research and method in Education (iosr jrme) Education of the deprived social group. With special reference to the girls education of Tinsukia district through $\mathrm{kGBv}$ 